\title{
Spatial and temporal characterization of some water quality physical parameters and their relationships with land-use in Água Fria watershed (Palmas - TO, Brazil) \\ (doi:10.4136/ambi-agua.17)
}

\author{
Alexandre Marco Silva1; Harry Edmar Schulz \\ ${ }^{1}$ Departamento de Engenharia Ambiental, UNESP, Sorocaba, SP, Brasil \\ E-mail: amsilva@sorocaba.unesp.br \\ ${ }^{2}$ Departamento de Hidráulica e Saneamento, Escola de Engenharia de São Carlos, USP, SP, Brasil \\ E-mail: heschulz@sc.usp.br
}

\begin{abstract}
Due to a high population growth that has been occurring in Palmas and due to land use changes that are caused by this population growth and development, the goal of this paper was to study the behavior of four physical parameters of water quality of the Água Fria watershed. The parameters were turbidity, total suspended solids, settleable solids and total dissolved solids. Eight gauging stations were established and the water samples were monthly collected from February/1998 to February/1999. The water bodies of the watershed were generally in good condition concerning these four parameters. However, there were some cases of seasonal irregularity of some parameters, as well as no correlation among some of studied parameters. This might be an indicator of some impacts like accelerated erosion due to a misuse of the lands and misuse of local water resources.
\end{abstract}

Keywords: water quality indicators; sediment pollution; watershed; Palmas-Tocantins, Brazil.

\section{Caracterização Espacial e temporal de alguns parâmetros físicos de qualidade da água e suas relações com o uso da terra na microbacia do Ribeirão Água Fria (Palmas - TO)}

\section{RESUMO}

Devido ao alto crescimento populacional ocorrente em Palmas e devido também às mudanças de uso da terra que são causadas devido a este crescimento, o objetivo deste trabalho foi estudar o comportamento de quatro parâmetros físicos indicadores de qualidade de água em corpos d’água localizados na microbacia do Ribeirão Água Fria. Os parâmetros estudados foram turbidez, sólidos suspensos totais, sólidos sedimentáveis e sólidos totais dissolvidos. Oito pontos de amostragem de água foram estabelecidos e as coletas procederamse mensalmente entre fevereiro de 1998 e fevereiro de 1999. Os corpos d'água da microbacia do Ribeirão Água Fria estavam em condições gerais consideradas satisfatórias com relação a estes quatro parâmetros. Contudo, notou-se certa irregularidade sazonal de alguns parâmetros, bem como correlações não significativas entre alguns dos parâmetros estudados. Isto pode ser um indicador de um início de degradação da qualidade da água devido a causas como erosão acelerada e uso não planejado dos recursos hídricos locais.

Palavras-chave: indicadores de qualidade da água; poluição por sedimentos; microbacia hidrográfica; Palmas, TO. 


\section{INTRODUCTION}

Sediment comes from soil erosion and suspended solids from watershed surfaces. Sediment is a natural component of streams, but excessive sediment can be carried into streams from erosion of unstable streambanks, construction sites, agricultural activities, and urban runoff. During erosion, the selectivity on the removal phase and transport of the particles results in a very rich sediment with higher amount of nutrients, organic matter and clay than the original soil where the particle was removed (Sparovek, 1996). If runoff occurs, the clay and organic matter, which are finer particles, are transported easier and faster than the coarser fractions (Bertoni; Lombardi Neto, 1990).

In the complete erosion-sedimentation cycle, the consequences of erosion are not only concerned with the soil loss but also with the transport of sediments and organic material into the rivers and their deposition (Beasley, 1972; Carvalho, 1998). Sediment is likely the most significant of all pollutants in relation to concentration in the water, its impacts on the water use, and its effects on the transport of other pollutants (Ward; Elliot, 1995). It is a significant pollutant in many Brazilian watersheds. Excessive sediment concentrations in the water column can be harmful to aquatic life and will exacerbate the toxic effects of other pollutants. Sediment deposits within streams degrade habitat for macroinvertebrates and fish communities. Finally sediment carries other types of contaminants into the aquatic system such as nutrients, organic compounds (e.g. pesticides), and heavy metals (Esteves, 1988).

There are several parameters that indicate the degree of influence of the sediment on the water quality. Turbidity, one of the most widely used, is a measure of the collective optical properties of a water sample that causes light to be scattered and absorbed rather than transmitted in straight lines. The Turbidity, when measured in Nephelometric Turbidity Units (NTU), uses nephelometric methods that depend on passing specific light of a specific wavelength through the sample (Eaton et al., 1995).

The Settleable Solid (S.S.) is another parameter widely used to characterize water quality. It is defined as the amount of solids that will settle under quiescent conditions in the influence of gravity. It may be determined and reported in either a volume $\left(\mathrm{ml}^{-1} \mathrm{l}^{-1}\right)$ or weight basis (mg. l $^{-1}$ ) (Eaton et al., 1995).

Total dissolved solids (T.D.S.) comprise inorganic salts and small amounts of organic matter that are dissolved in water. The principal constituents are usually the cations calcium, magnesium, sodium and potassium; and the anions carbonate, bicarbonate, chloride, sulphate and nitrate. The concentration of TDS in water in contact with granite, siliceous sand, wellleached soil or other relatively insoluble materials is usually below $30 \mathrm{mg} . \mathrm{l}^{-1}$. At levels above $500 \mathrm{mg} . \mathrm{l}^{-1}$, excessive hardness, unpalatability, mineral deposition and corrosion may occur. At lower levels, however, TDS contributes to turn better the water palatability (Eaton et al., 1995).

Total suspended solids (T.S.S.) concentrations indicate the amount of suspended solids in water, whether mineral (e.g., soil particles) or organic (e.g., algae). The T.S.S. test measures an actual weight of material per volume of water. TSS concentrations are reported in units of milligrams of suspended solids per liter of water - mg. $^{-1}$. High concentrations of particulate matter affect light penetration and primary productivity, recreational values, and habitat quality of the affected environment. Particles also provide the aggregation of other particulate pollutants, notably metals and bacteria (Azevedo Netto, 1991; Eaton et al., 1995).

Indirectly, the suspended solids affect other parameters such as temperature and dissolved oxygen. Because of the greater heat absorbance of the particulate matter, the surface water becomes warmer and this tends to stabilize the stratification (layering) in stream pools, 
embayment, and reservoirs. This, consecutively, interferes with mixing, decreasing the dispersion of oxygen in deeper layers.

Suspended solids (S.S.) cause interference in the effective drinking water treatment. High sediment loads interfere with coagulation, filtration, and disinfection. More chlorine is required to effectively disinfect turbid water. They also cause problems for industrial users. Suspended sediments also interfere with recreational use and aesthetic enjoyment of water.

Sediment deposition eventually may close up channels or fill up the water body converting it into a wetland. A positive effect of the presence of suspended solids in water is that toxic chemicals such as pesticides and metals tend to adsorb to them or become complexed with them which make the toxics less available to be absorbed by living organisms.

The central region of the Tocantins state (Brazilian Northern region), most precisely its capital (Palmas), has as been experimenting high rates of human population and urbanization. Palmas is a young city that in 1989 was created to be the business and politic center of Tocantins State. Then, high rates of deforestation and increased negative impacts of land cover change on water quality of the streams that pass through the city are starting to emerge, and may be related to increasing human population (due mainly to migration).

The aim of this paper was to determine if the physical condition of the streams located in the Água Fria watershed (Palmas - Tocantins, Brazil) have been altered due to increasing human population and land use development.

\section{The Study Site}

The Água Fria watershed has $7.6 \mathrm{Km}^{2}$ and is fully inserted in the municipal area of Palmas (Tocantins, Brazilian northern region). Geographical coordinates are: $48^{\circ} 16^{\prime}$ and $48^{\circ}$ $23^{\prime}$ west longitude and $10^{\circ} 03^{\prime}$ and $10^{\circ} 20^{\prime}$ south latitude (Silva, 1999). The main climatic characteristics observed indy area are annual average temperature $24^{\circ} \mathrm{C}$ and annual average rainfall depth 1,300 mm (Nimer, 1979).

The relief of the Água Fria watershed is steep on the headwater regions (high parts of the watershed) and smoothly waved near the estuary. Along the steepest region, geologic basement is crystalline and in regions where the relief is smoothly waved the geologic basement is sedimentary (Brasil, 1981).

The soil classes that are found on the study area (Ranzani, 1998) are (according to F.A.O. classification system): Plinthosol, occurring on 27.8\% of the area; Rhodic Ferralsol (28.0\%); Leptosol (10.3\%); Xanthic Ferralsol (17.3\%); Cambissol (8.0\%); Gleysol (7.6\%). Bare rock is also found in $1.0 \%$ of the area.

Hydrography of the Água Fria watershed is composed of three main water courses: Brejo Comprido, Suçuapara and Água Fria. The headwaters of the Água Fria and Brejo Comprido are located in the Lajeado's hill, while the Suçuapara has its unique headwater located in the city of Palmas, where the relief is smoothly waved. This watershed has crucial importance for the population that lives in Palmas because a significant part of the drinking water that is consumed in the city comes from the Água Fria stream.

The main land use classes used in this study are: water bodies (occupying $0.27 \%$ of the total area), areas for environmental protection (68.28\%), agricultural areas (61.80\%), urban settlement (30.45\%) and areas experimenting urban expansion (6.74\%). In the Area for Environmental Protection (named "Área de Proteção Ambiental da Serra do Lajeado") the predominant land cover is natural vegetation, despite of presenting some unpaved roads and some patches with burnt vegetation (especially in the dry season). The "water bodies" class represents some small dams and lakes found along the study area. 


\section{METHODS}

Eight gauging stations were established along the Água Fria watershed (Figure 1). These stations were established according to the accessibility and local. During the period from Feb/1998 to Jan/1999 three water samples (approximately 2 liters) were collected according to the vertical integration method described by Carvalho (1994).

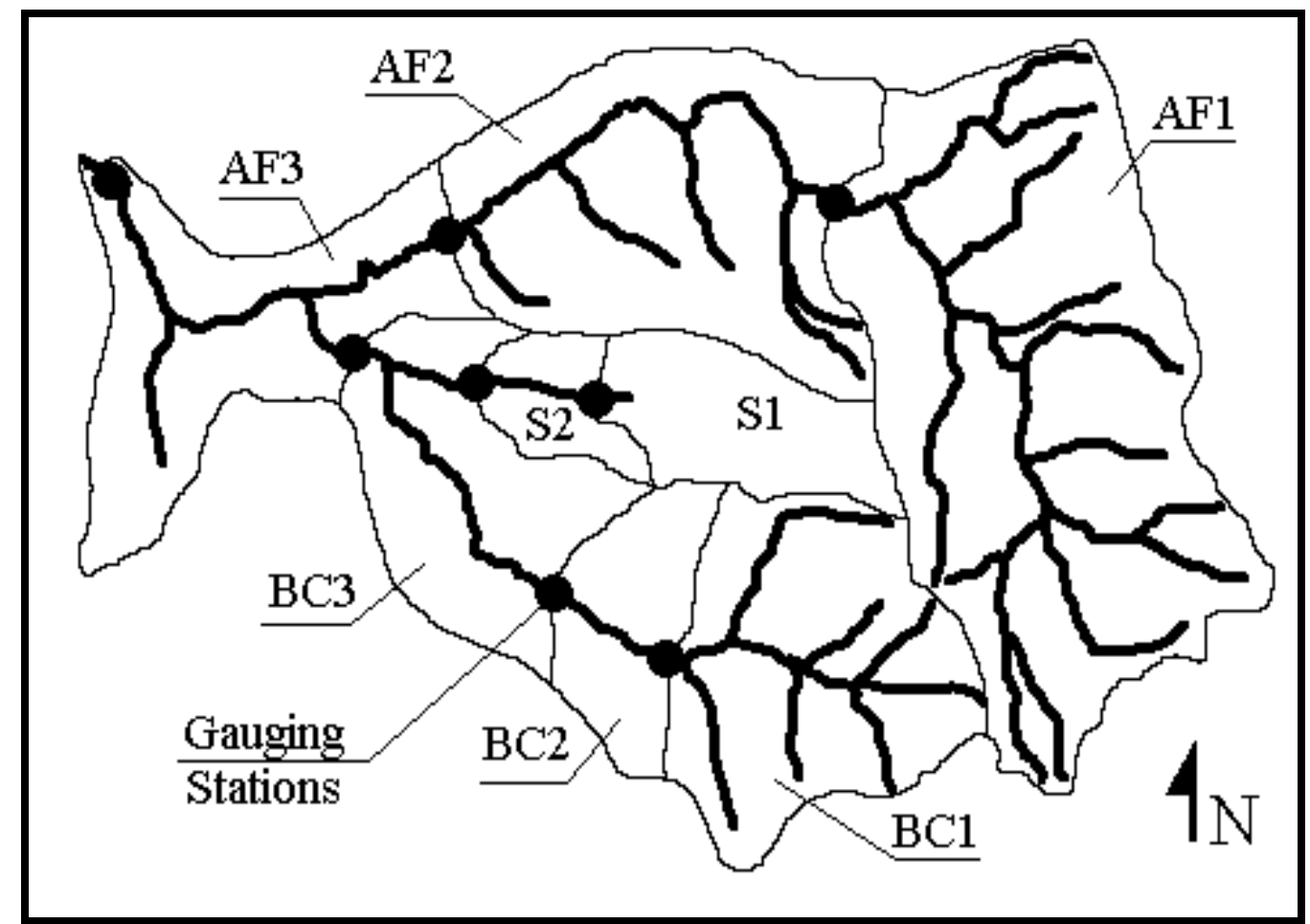

Figure 1. Map showing the eight stations established. The division lines of the sub watersheds were determined according to the topography of the region.

In laboratory total dissolved solids were quantified using the evaporation method (Gandolfi, 1971; Eaton et al., 1995; Pião, 1995). Settleable solids were quantified with an Imhoff cone (1 liter sample / 1 hour time - see more details in Eaton et al., 1995). Turbidity was quantified with a Hach 2100P turbidimeter. Dissolved solids were quantified with a Prob 50161 conductivimeter. The parameter Dissolved Solids was not quantified for the February/1998 because the conductivity meter was out of work. The spatial and temporal variations were compared through the determination of the variation coefficient (eq. 1).

$$
\mathrm{VC}(\%)=\frac{\mathrm{S}_{\mathrm{i}}}{\overline{\mathrm{X}_{\mathrm{i}}}} * 100
$$

where:

$\mathrm{VC}$ - variation coefficient (\%).

$\mathrm{S}_{\mathrm{i}}$ - Standard deviation of the monthly values of the parameter "i".

$\bar{X}_{i}$ - Mean value of the monthly values of the parameter “i”.

A correlation matrix among the parameters was computed. 


\section{RESULTS AND DISCUSSION}

Figure 2 shows the seasonal variation of turbidity values for the eight sub watersheds during the study period. The values of turbidity ranged from 2.3 to $215.0 \mathrm{NTU}$ and in most occasions the values were considered low. According to Mota (1995), values higher than 100 NTU indicate that the water resource cannot be used for recreation activities. Just in five occasions the values were higher than 100 NTU. This indicates that the water was still good for recreational purposes almost all year long. The spatial variability was smaller than the temporal variability (V.C. $84.4 \%$ and $100.1 \%$, respectively).

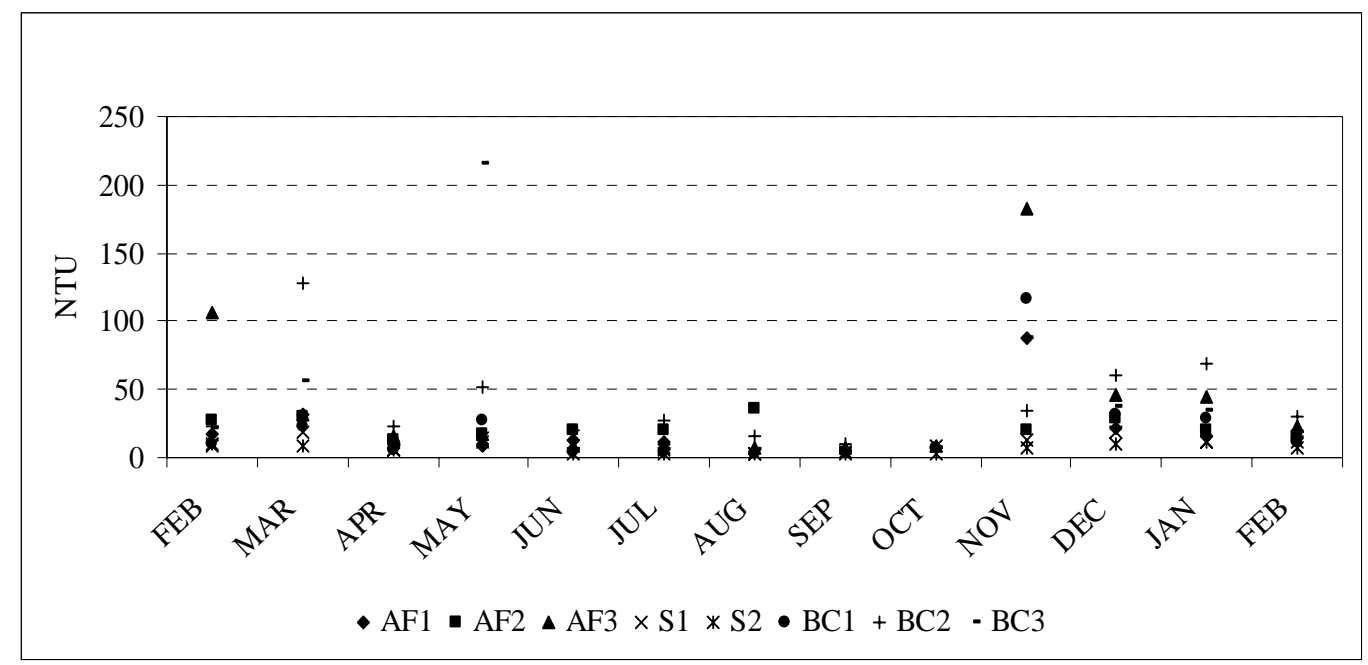

Figure 2. Monthly values of Turbidity for the study area.

Three sub-watersheds presented similar annual values of turbidity (average monthly values): AF3, BC2 and BC3 (respectively 38.8, 38.4 and 38.9 NTU). BC2 presented the highest value for seven months, while AF1, S2 and BC1 did not presented an extremely high value in any month. It is interesting to note that the BC2 station was located 150 meters downstream of the Parque Cesamar's lake (a recreational area). In both BC2 and BC3 subwatersheds some gullies were observed near Brejo Comprido stream. This might be an important source of sediment that modify water quality and fluvial characteristics of the water bodies (Silva, 1999).

For the parameter Dissolved Solids the values were also low during the study period for all gauging stations. The values ranged from 0.9 to $13.0 \mathrm{mg} . \mathrm{l}^{-1}$. The AF1 sub-watershed presented the highest average value $\left(9.3 \mathrm{mg}^{-1} \mathrm{l}^{-1}\right)$. The monthly values of dissolved solids are shown in Figure 3.

This parameter presented spatial variability higher than the temporal variability (V.C. $32.6 \%$ and $27.8 \%$ respectively), although both variations were low. The annual average value for the study area was $5.8 \mathrm{mg} . \mathrm{l}^{-1}$. The average value for the dry season was $4.8 \mathrm{mg} . \mathrm{l}^{-1}$ while the average value for the wet season was $6.8 \mathrm{mg}^{-1}{ }^{-1}$.

Christofoletti (1981) shows values of dissolved solids for many rivers of the Amazon region and in a general way the values ranged from 4.0 to $248.0 \mathrm{mg} . \mathrm{l}^{-1}$. For the Negro river basin the average value was $6.0 \mathrm{mg}^{-1} \mathrm{l}^{-1}$ in the dry season and $4.0 \mathrm{mg} . \mathrm{l}^{-1}$ in the wet season, while for the Madeira river basin the average values were $68.0 \mathrm{mg} . \mathrm{l}^{-1}$ in dry season and 50.0 mg. $\mathrm{l}^{-1}$ in the wet season. 

and their relationships with land-use in Água Fria watershed (Palmas - TO, Brazil). Ambi-Agua, Taubaté, v. 2, n. 1, p. 21-29, 2007. (doi:10.4136/ambi-agua.17)

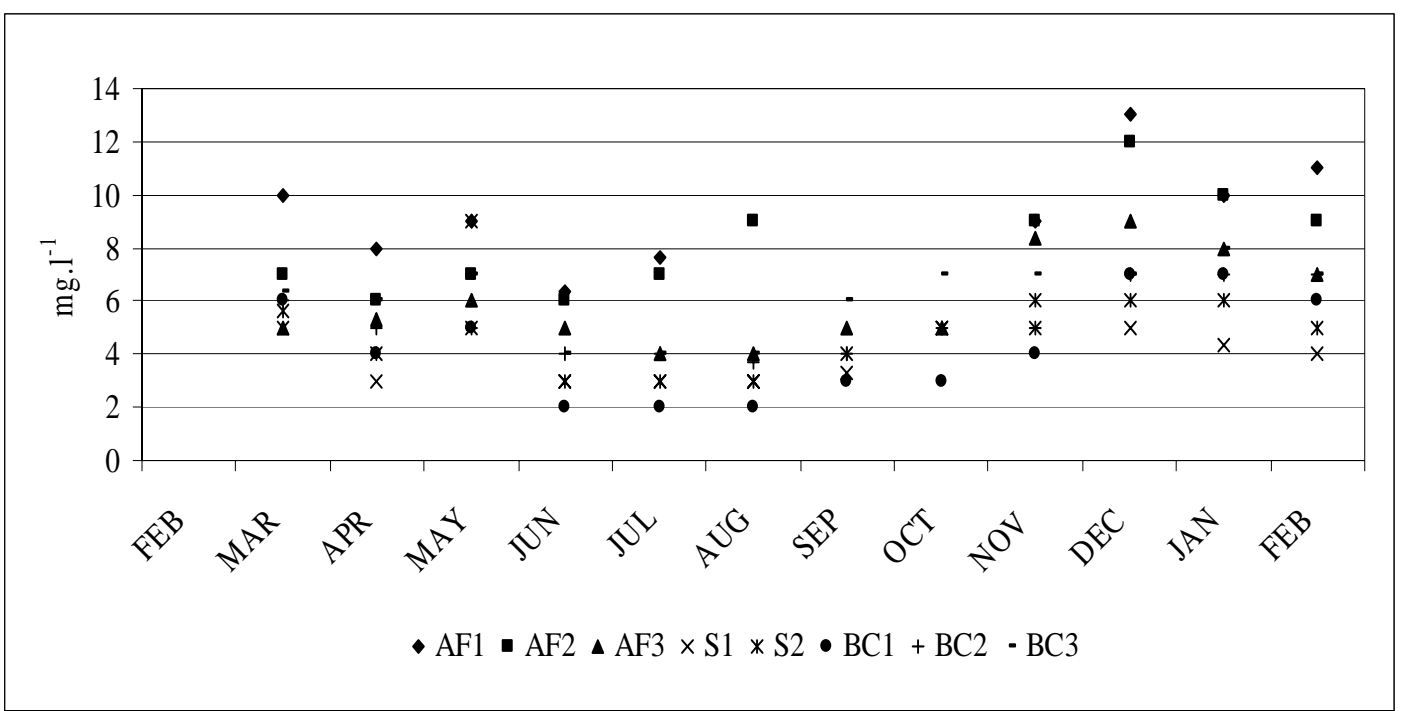

Figure 3. Monthly values for Dissolved Solids.

Regarding the values shown by Christofoletti (1981) for the Amazon region, the values of dissolved solids for the dry season were higher than the values for the wet season in all watersheds. This fact does not agree with the values found on this study, and may indicate and anomaly associated with the water characteristics of the streams.

Similarly, Daniel et al. (2002) showed, graphically, some abnormality on the seasonality of the Electric Conductivity (an indirect indicator of the amount of dissolved solids in water) for ten sub-watersheds of the Piracicaba river basin (SP, Brazil). The authors associated those results mainly to the dispersal of untreated urban sewage into the streams. For Água Fria watershed, despite of having a percentage of urban area proportionally higher than this other study (Água Fria: 20\% and the other cases approximately 15\%), the domestic sewage is still discharged into septic tanks. On the other hand, many people have used the streams for washing cars, depositing solid waste, and other purposes that might cause the degradation of the study area water bodies.

Total Suspended Solids showed the highest temporal variation among all parameters during the study period (V.C. $111.3 \%$ ), while the spatial variation was V.C. 52.5\%. The values ranged from 45.3 to $4,841.0 \mathrm{mg} . \mathrm{l}^{-1}$ and the mean value obtained for the watershed

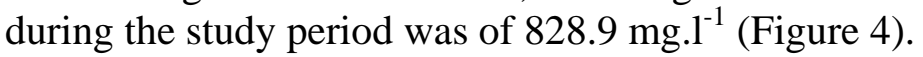

This average value found for this watershed contradicts the founding of Christofoletti (1981) who stated that in Brazilian rivers the amount of suspended material is normally low (smaller than $100 \mathrm{mg}^{-1} \mathrm{l}^{-1}$ ). For the Amazon River, for instance, the author shows an average value of 90 mg. $\mathrm{l}^{-1}$ with the values ranging from $1 \mathrm{mg} . \mathrm{l}^{-1}$ in the dry season for the Negro, Tapajós and Xingu rivers to $728 \mathrm{mg}^{-1} \mathrm{l}^{-1}$ in the wet season for the Ucaiali River. On the other hand, the same author presented values of $43 \mathrm{mg} . \mathrm{l}^{-1}$ of dissolved material and $550 \mathrm{mg} . \mathrm{l}^{-1}$ of particle material in the dry season and values of $10 \mathrm{mg} \cdot \mathrm{l}^{-1}$ of dissolved material and 1,200 mg. $\mathrm{l}^{-1}$ of particle material in the wet season for Paraíba do Sul River (Barra do Piraí, RJ southeast region of Brazil).

Mota (1995) showed for São Carlos-SP (southeast region of Brazil) values ranging from 171.0 to $3,499.0 \mathrm{mg} . \mathrm{l}^{-1}$ for urban runoff waters. This shows that when the watershed is largely urbanized one of the main environmental disturbances that occurs is the change on sedimentological balance, as also affirmed by Wilson Jr. (1996). 
SILVA, A. M.; SCHULZ, H. E. Spatial and temporal characterization of some water quality physical parameters and their relationships with land-use in Água Fria watershed (Palmas - TO, Brazil). Ambi-Agua, Taubaté, v. 2, n. 1, p. 21-29, 2007. (doi:10.4136/ambi-agua.17)

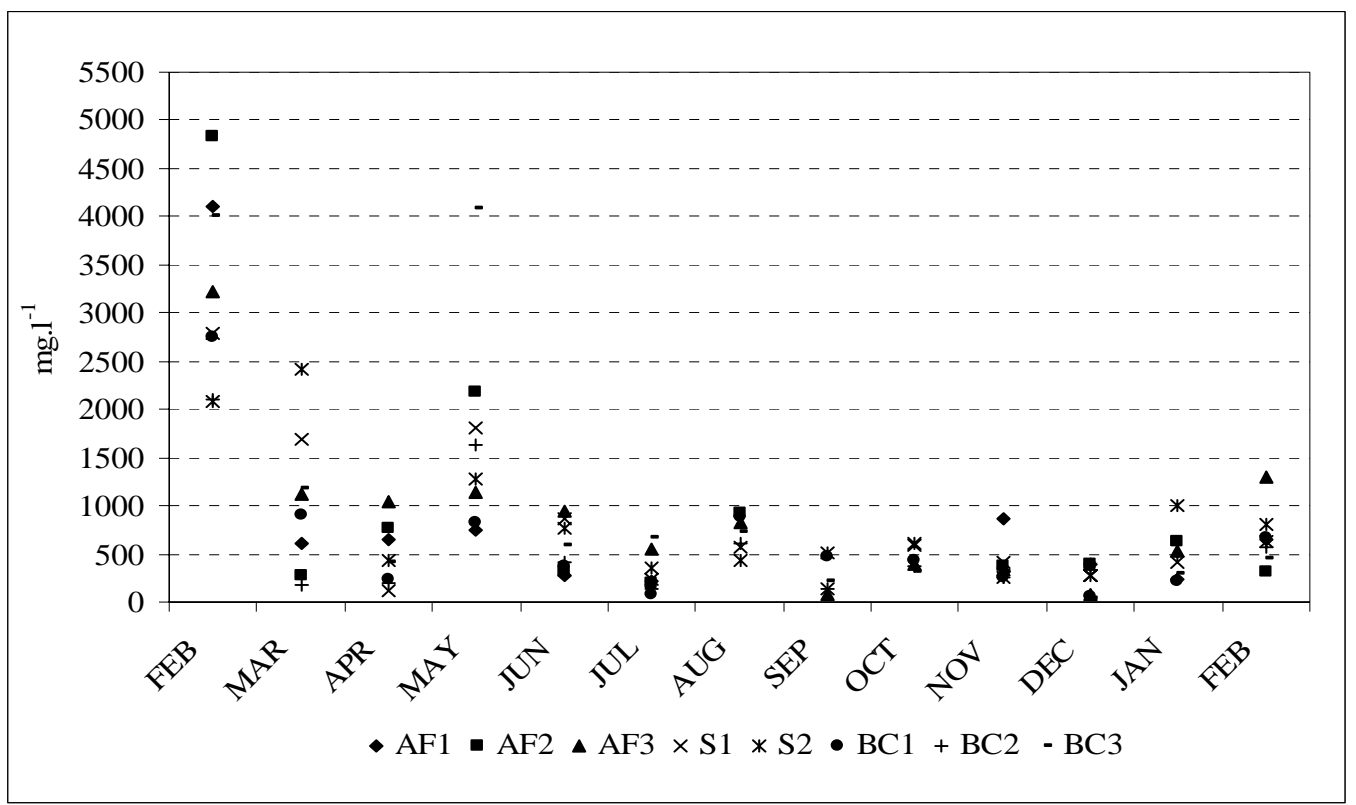

Figure 4. Monthly values of Total Suspended Solids for the study area.

Settleable solids ranged from 0.01 to $5.13 \mathrm{ml}^{-\mathrm{l}^{-1}}$. Significant correlation $(\mathrm{r}=0.65$, significant $\alpha=1 \%$ ) between settleable solids and water flow was found (water flow values were obtained in Silva and Schulz (in press)). AF3 was the sub-watershed that presented the highest values almost all year long, except September and October (Figure 5), when the S1 sub-watershed presented the highest values. Despite this seasonal situation observed in the study area, it is impossible to state that urbanization had expressive influence in the values of this parameter. Because, differently than expected, the BC3 sub-watershed (located downstream of the urban settlement) did not show similar results. Therefore, the erosion process (channel erosion) might be the main environmental degradation agent that occurred in the AF3 sub watershed along with the main type of soil (sandy gleysol), reported by Silva (1999).

The results obtained by correlation analysis are shown on Table 1 . The turbidity showed significant correlation with all parameters studied. It can be seen that this parameter is the most affected by the presence of sediment, as also reported by Azevedo Netto (1991) and Ward and Elliot (1995). Despite the significant correlation found among turbidity and other parameters, it is important to say that the turbidity is a qualitative parameter and cannot be considered directly as amount of suspended solids per liter, as discussed by Riley (1998). This affirmation can be supported by the significant but "low" " $r$ " value found between total suspended solids and turbidity $(\mathrm{r}=0.33)$. This correlation may occasionally present a high $\mathrm{r}$ value, probably in pristine water bodies.

Table 1. Correlation matrix among the monthly values of water flow (FLOW), settleable solids (S.S.), total suspended solids (T.S.S.), turbidity (TURB) and dissolved solids (D.S.).

\begin{tabular}{|c|c|c|c|c|c|c|c|c|}
\hline & \multicolumn{2}{|c|}{ S.S. } & \multicolumn{2}{|c|}{ T.S.S. } & \multicolumn{2}{|c|}{ TURB } & \multicolumn{2}{|c|}{ D.S. } \\
\hline FLOW & 0.65 & $(* *)$ & 0.21 & $(*)$ & 0.29 & $(* *)$ & 0.20 & \\
\hline S. S. & & & 0.13 & & 0.25 & $(*)$ & -0.04 & \\
\hline T.S.S. & & & & & 0.33 & $(* *)$ & 0.10 & \\
\hline TURB & & & & & & & 0.29 & $(* *)$ \\
\hline
\end{tabular}




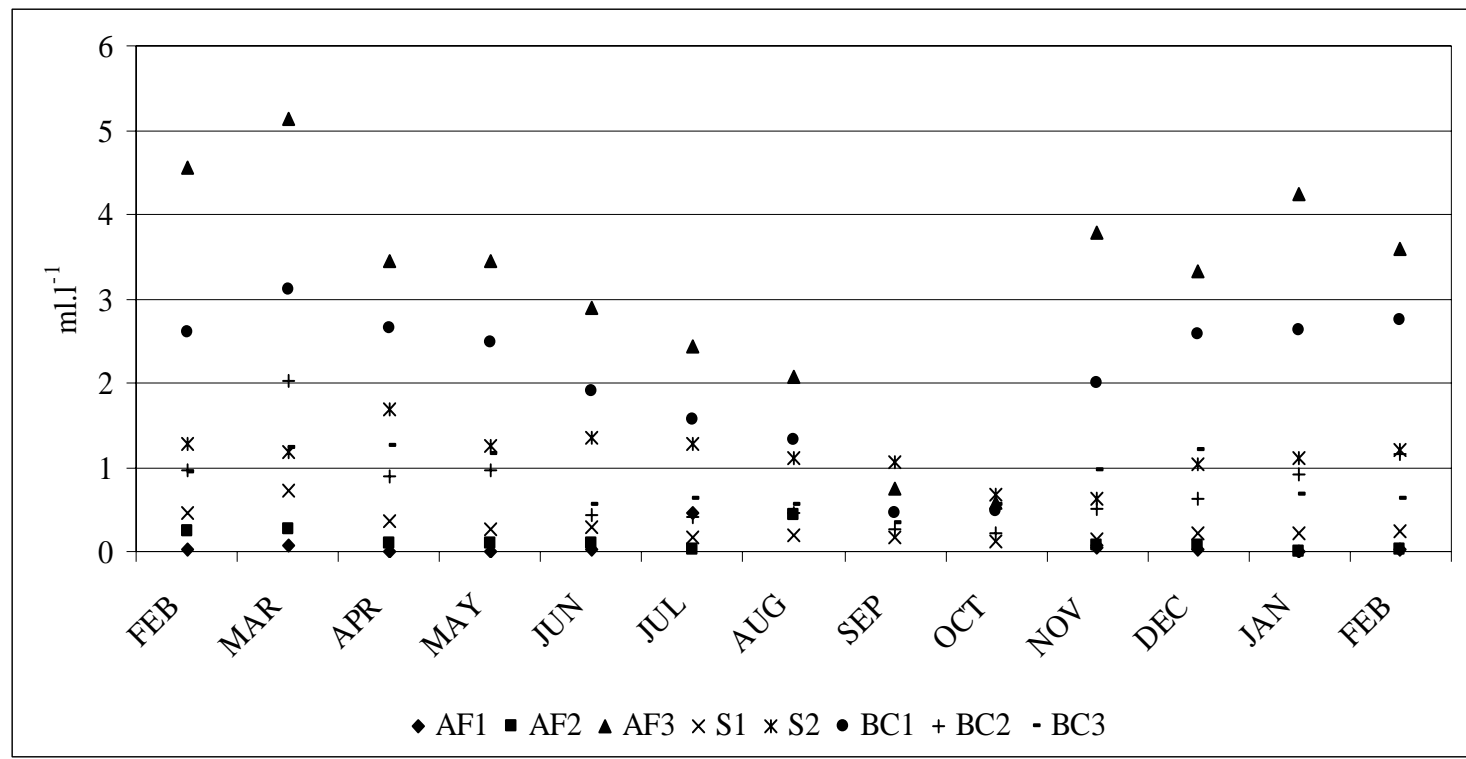

Figure 5. Monthly values of Settleable Solids for study area.

\section{CONCLUSIONS}

The four water quality indicators studied showed that water quality of the Água Fria watershed streams were still in good condition. But the non-correlation observed between some parameters suggests that some equilibrium modification of the hydrosedimentological cycle might be already ccurring. This imbalance may be due to the intensive misuse of this water resource for many purposes.

\section{ACKNOWLEDGEMENTS}

We thank Odo Primavesi and Hélio do Prado for help on translate of the soil classes from Brazilian to International System. We also thank CNPq by financial support.

\section{REFERENCES}

AZEVEDO NETTO, J. M. Manual de saneamento de cidades e edificações. São Paulo: PINI, 1991.

BEASLEY, R. P. Erosion and sediment pollution control. Iowa: University Press, 1972.

BERTONI, J.; LOMBARDI NETO, F. Conservação do Solo. São Paulo: Ícone, 1990.

BRASIL. Ministério de Minas e Energias. Departamento Nacional de Produção Mineral. Projeto RadamBrasil. Levantamento dos recursos naturais: folha SC 22: Tocantins. Rio de Janeiro: [S.n.], 1981.

CARVALHO, N. O. Assoreamento e proteção de reservatórios. In: NATIONAL SYMPOSIUM OF EROSION CONTROL, 6., 1998, Presidente Prudente. Proceedings... Presidente Prudente: [S.n.], 1998. 1 CD-ROM.

Hidrossedimentologia prática. Rio de Janeiro: CPRM, 1994.

CHRISTOFOLETTI, A. Geomorfologia fluvial. São Paulo: Edgard Blücher, 1981. 
DANIEL, M. H. B.; MONTEBELO, A. A.; BERNARDES, M. C.; OMETTO, J. P. H. B.; et al. Effects on urban sewage on dissolved oxygen, dissolved inorganic and organic carbon, and electrical conductivity on small streams along a gradient of urbanization in the Piracicaba river basin. Water, Air, and Soil Pollution, Dordrecht, v. 136, p.189206, 2002.

EATON, A. D.; CLESCERI, L. S.; GREENBERG, A. E. Standard methods for examination of water and waster water. 19 ed. Washington: EPA/APHA, 1995.

ESTEVES, F. A. Fundamentos de limnologia. Rio de Janeiro: FINEP, 1988.

GANDOLFI, N. Investigações sedimentológicas, morfométricas e físico-químicas nas bacias do Moji-Guaçu, do Ribeira e do Peixe. 1971. Tese (Livre-Docência) Departamento de Geologia e Mecânica dos Solos, Escola de Engenharia de São Carlos, Universidade de São Paulo, São Carlos, 1971.

MOTA, S. Preservação e conservação dos recursos hídricos. 2 ed. Rio de Janeiro: ABES, 1995.

NIMER, E. Climatologia do Brasil. Rio de Janeiro: Fundação IBGE, 1979. (Série Recursos Naturais e Meio Ambiente, 4).

PIÃO, A. C. Transporte de nitrogênio, fósforo e sedimentos pelo Ribeirão dos Carrapatos (Município de Itaí - SP), sua relação com usos do solo e outros impactos antropogênicos e a sua deposição no braço do Taquari (Represa de Jurumirim). 1995. Tese (Doutorado em Engenharia Ambiental) - Escola de Engenharia de São Carlos, Universidade de São Paulo, São Carlos, 1995.

RANZANI, G. Mapa de solos do município de Palmas, TO. [S.l.]: [S.n.], 1998. Escala $1: 100.000$.

RILEY, S. J. The sediment concentration-turbidity relation: its value in monitoring at Ranger Uranium Mine, Northern Territory, Australia. Catena, Kingswood, v. 32, n. 1, p. 1-14, 1998.

SILVA, A. M. Aplicações de técnicas de geoprocessamento no estudo das relações entre os processos erosivos e sedimentológicos de bacia hidrográfica. 1999. Tese (Doutorado em Engenharia Ambiental) - Escola de Engenharia de São Carlos, Universidade de São Paulo, São Carlos, 1999.

SILVA, A. M., SCHULZ, H. E. - Hydrosedimentological dynamic on Água Fria watershed (Palmas, TO) - Brazil). Brazilian Archives of Biology and Technology, Curitiba, in press. (http://everest3.tecpar.br/babt/).

SPAROVEK, G. Erosão do solo e a produtividade das culturas. In: LATIN-AMERICAN CONGRESS OF SOIL SCIENCE, 13., 1996, Águas de Lindóia. Proceedings... Águas de Lindóia: SBCS/USP-ESALQ, 1996. 1 CD-ROM.

WARD, A. D.; ELLIOT, W. J. Environmental hydrology. Boca Raton: Lewis Publishers, 1995.

WILSON JR., G. Quando os sedimentos se tornam poluentes. In: BRAZILIAN NATIONAL MEETING OF SEDIMENT ENGINEERING, 2., 1996, Rio de Janeiro. Proceedings... Rio de Janeiro: [S.n.], 1996. 